\title{
Sandwich Courses in Higher Education: From Transmitting Knowledge to Building Regional Brand Lessons Learned From the Corsica-region University-sponsored Placements \& Careers Service (CFA UNIV) Experience
}

\author{
Christophe Storaï, Laurent Marinetti \\ University of Corsica, Corte, France
}

\begin{abstract}
Long confined to early pre-tertiary school-leaver training and often synonymous with academic failure, sandwich training has experienced a remarkable turnaround, debunking common misconceptions and gaining ground in higher education. Sandwich training improves academic success rates and school-to-work transition prospects, making it both a pathway to excellence and a gateway into employment by keeping a clear tack in the face of social-economic headwinds - especially for young graduates. The factors involved are primarily education-driven (academic success, best-in-class graduates, and etc.), but where sandwich training really floats is in the job market, by co-potentializing both school-to-work transition and employability. The Corsica-region University-sponsored Placements \& Apprenticeships Service (CFA UNIV), as regional leader in post-secondary sandwich placement ( $65 \%$ of sandwich-placement students in Corsica), is therefore structurally engaged as a facilitator of the island-wide economy, providing business and industry with a pipeline of core skill sets while readying them to rise to tomorrow's economic and human resources (HR) challenges. This paper attempts to highlight this very real trajectory by reporting the lessons learned from Corsica-region CFA UNIV experience.
\end{abstract}

Keywords: Sandwich course, mentorship, apprenticeship mentor, employability, homo alternans

\section{Introduction}

The French law relative to the Liberties and the Responsibilities of University (LRU University) Autonomy and Accountabilities Reform of 10 August 2007 makes vocational readiness and school-to-work transition core public service policy missions for higher education. Under LRU law, all higher education institutions are required to publish a number of statistics, including indicators on career placement rates. In its 2008 to 2011 institutional contract, the University of Corsica set out a number of major strategic orientations, one of which was to extend its sandwich-placement training offer (courses accessible through the signature of apprenticeship training or vocational qualifications agreements). A new intra-university structure was created

Christophe Storaï, senior lecturer in Economics, UMR LISA 6134, Corsica-region University-sponsored Placements \& Apprenticeships Service (CFA UNIV) in Corsican region, University of Corsica, Corte, France.

Laurent Marinetti, skills development consultant, Corsica-region University-sponsored Placements \& Apprenticeships Service (CFA UNIV) in Corsican region, University of Corsica, Corte, France.

Correspondence concerning this article should be addressed to Christophe Storaï, CFA UNIV in Corsican region, Campus GRIMALDI, Bat PPDB, University of Corsica, 20250 Corte, France. E-mail: storai@univ-corse.fr. 
specifically for this purpose: Corsica-region University-sponsored Placements \& Apprenticeships Service (CFA UNIV). Now as a leader of the sandwich-course training system in higher education in Corsica, the CFA UNIV has forged a position as structurally engaged facilitator of island-wide spatial planning and regional branding.

Corsica offers a case-in-point example of an areal region characterized by an ageing labour force, making it necessary to re-align mid-term regional vocational training strategy in response to this inescapable reality. As a major lever of local-regional development and social regulation policy, the island's vocational training system has to re-adapt its offer to achieve the targeted job-to-training fit. The overhaul hinges on impelling a sustained strategy to develop partnerships with the island's key social and economic communities (businesses, community groups, local authorities, and government agencies handling subsidized professional training) that can play a fundamental role in shaping and selling the most vital valued assets that typify a regional territory emerging into a structured destination-brand identity (simultaneous growth in the employability and quality of school-to-work transition shown by its human capital, mass shift in the degree of skill acquisition directly tied to the regional territory's own organic needs, fluidity of knowledge transfer fully controlled through sandwich placements, deep sustainable entrepreneurship education, and so on).

In a period where unemployment—especially graduate unemployment—has hit new highs, sandwich-placement paths to university degrees have stolen the headlines. How has this trajectory emerged over the last five-year term? What are the factors that make sandwich courses in higher education both a conservative yet value-adding system? This paper analyzes the lessons learned from the latest three surveys of University of Corsica sandwich-placement leavers and the feedback from scheme-partner business leaders who have recruited several sandwich-placement students since 2009 (Storaï, Riniéri, \& Boulenger, 2014). This grass-roots reality could also inform the wider initiative to build a policy decision support tool focused on the theme of areal planning and regional branding for Corsica.

\section{Transmitting Knowledge As a Fundamental Rule}

A sandwich placement (apprenticeship training or vocational qualifications agreement) hinges on a two-person team (in-company mentor/apprenticeship mentor and in-university course tutor/placement tutor) that is critical to lasting placement success.

The in-company mentor/apprenticeship mentor, as cornerstone of the system, is tasked with facilitating placement-student integration and guiding them towards a career by enabling them to acquire professional knowledge, skills, and competencies via on-the-job training. The mentor transmits and transfers company know-how, turns work situations into learning opportunities, and coaches their protégé through the process of integrating the company-and sometimes even corporate culture. Apprenticeship mentors are assigned to apprentices on every type of sandwich placement program. In theory, apprenticeship mentors hold professional titles or diplomas in their specialized profession and at least the same level of qualification as the student is working towards plus three years of appropriate on-the-job experience. The in-company mentor's primary role is to supervise the junior in an effort to maximize cross-generational knowledge transfer and thereby lay the foundations for developing the key pre-requisites for recruitment and retention.

Sandwich-placement training revolves around a placement service-university-company trifecta articulated around the student-junior. Each of these three organizations provides the learner with end-to-end support throughout their training. The sandwich student is in direct two-way engagement with this trifecta, both physically and administratively. The support offered is tangible at both organizational and supervisional level. 
Here, it will see how the sandwich-scheme governance system requires heavy organizational support, with a key role divested to the tutor.

\section{Mentorship: A System of Learning Personified by the in-company Mentor}

The human resources (HR) function is split (Peretti, 2001) among several actors in the company (Thevenet, Dejoux, Marbot, \& Normand, 2007). In any deployment of competency management policy, the manager plays a pivotal role (Bernardin \& Krohmer, 2007), both as decision-leader and through the educational and persuasive skills they are expected to develop. In the sandwich placement system, the manager or superior/supervisor will almost always be the placement student's in-company mentor. What roles does he/she embody? What effects are lent to him/her? To find the answers, authors have to start back at the definition of mentorship.

Mentorship is innate to sandwich training (Lankau \& Scandura, 2002; Eby \& Lockwood, 2005), as it stems from the buddy system and the apprenticeship-framed mentor/mentee relationship. Logically, then, any initiative to accelerate skills transfer through mentorship will implicitly involve an essentially apprenticeship-type framework. In the past, every apprenticeship mentor was expected to pass on what he himself has learned. Mentorship is thus an inductive approach to teaching grounded in guided on-the-job experience (Fredy-Planchot, 2007).

There is a principle of coordination tying apprentice to apprenticeship mentor on the basis of a specific employment contract ${ }^{1}$ and wrapped up by the CFA UNIV and the in-university placement tutor. For a student-apprentice, the placement tutor is the academy-side counterpart of the host business-side apprenticeship mentor. The mentorship effort involves a set of (chiefly human) resources that a company mobilizes for "on-the-job" integration and training (Clénet \& Demol, 2002). Mentorship started out as a discrete improvised practice (Vanderpotte, 1992) but has since grown to take on a shared meaning in which the mentor/mentee relationship is seen as a dynamically engaged interactive process of absorbing knowledge, in contrast to looser tacit or instructional vectors of transfer (Astier, Conjard, Devin, \& Olry, 2006).

This paper thus defines mentorship as the initiation of an intensive working relationship between a junior and a more experienced member of the organization tasked with preparing the junior to take up an incumbent role and facilitating their career development. This relationship offers businesses the opportunity to pass on vital competencies to the junior who, being university-trained, brings a fresh stream of thought and technology knowhow to their new host organization.

However, the in-company mentor has to meet legal conditions governing their mission as mentor (see earlier) and give exposure and visibility to skills and abilities that the apprentice can grasp in order to effectively maximize the relationship. Tying into social learning theory (Bandura, 1977), the student's willingness to learn is sharper, when the in-company mentor is perceived as credible and an expert, and when junior sees mentor's behaviour as an aspirational ideal (Noe, 2000), exemplifying natural leadership within the entrepreneurial structure (Allen \& Poteet, 1999). Over the relationship, competency acquisition is facilitated by the in-company mentor's role and power in the organization. Furthermore, the quality of the relationship forged between the two actors is a decisive factor of mentorship efficiency directly driven by frequency of opportunities for student-in-company mentor interaction. As the student's go-to-authority, the in-company mentor facilitates integration into the company or new job position by providing guidance and help with

\footnotetext{
${ }^{1}$ An apprenticeship training agreement
} 
gaining expertise in increasingly challenging assignments (Jedliczka \& Delahaye, 1994). The in-company mentor is partially responsible for the acquisition of job skills and soft skills as well as the coherency between academy-side training and company-side training (Luttringer, 1995).

\section{Support From the Supervisor: The Extended Reach of Mentorship}

Mentorship acts as a mediator between the placement student's personal development training and the organizational effects for the company (Lankau \& Scandura, 2002). The effects produced have a long-term spin-off. Over the course of the placement, the in-company mentor onboards the employee in the new workplace environment- - he/she sponsors the employee by helping them engage in job-related activities and understand the workings involved; passes on key competencies; enables information seeking and analysis; provides the means to effectuate learning activities; and evaluates the student (Boru \& Leborgne, 1992). This onboarding role, which goes well beyond the straight transmission of professional practices (Gerard, 2003), has knock-on effects in the organizational socialization process that the mentor initiates (Lacaze, 2004). Mentor-fostered integration helps the student "read" the company's corporate culture, key activities, organizational infrastructure, people, departments, and management styles (Veillard, 2004). By transmitting its culture, the organization embeds an identity that will serve to mobilize its staff on common-goal projects (Thevenet, 1992). Furthermore, on a more general level, the mentor personifies the company's role as facilitator to their employee/sandwich student. Clearly, then, on the HR front, mentorship is a strategic resource for an organization, galvanizing and accelerating the university-enterprise relationship that is so pivotal to the socioeconomic skills-driven regional branding effort.

Mentorship, reflected in the support of the supervisor, can adopt the same mechanism of mutual-benefit exchange as the organizational support personified by the mentor. If the actors feel that they have the support of their supervisor, he/she will adopt a behavior that is comfortable, complex-free, and therefore beneficial to the organization. Perceived supervisor support can be defined as the general perception that supervisors value employees' contributions and care about employees' well-being (Eisenberger, Fasolo, \& Davis-LaMastro, 1990; Manville, 2006). Perceived supervisor support will effectively translate a favorable work environment for employees (Stinglhamber \& Vandenberghe, 2003). A powerful affective psychological contract may even emerge (Schein, 1978). As supervisors act as the organization's main agents, perceived supervisor support will shape perceived organizational support (Rhoades \& Eisenberger, 2002) and bring about the effects, including in terms of organizational commitment. Individuals who have been mentored go on to show better career path planning, career engagement, and job satisfaction, are better paid. Tutoring facilitates career development by developing managerial abilities, technical abilities, a sense of competence and effectiveness, and the knowledge of how to adjust behavior to fit the expectations of different management echelons (Hunt \& Michael, 1983). Sandwich students are often getting their first taste of professional experience and forging their first opinion on the world of work. This first contact can prove decisive for their entire later career-the mentor's role is also to let the junior build their first attachment to the company, without slipping into utopian naivety but keeping hold of the most positive realistic vision possible.

\section{Coordination Role Divested to In-university Course Tutor/Placement Tutor}

In higher education in general and at the Corsica-region CFA UNIV in particular, an in-university course tutor or placement tutor is appointed to monitor the placement student's progress throughout their vocational training curriculum. The tutor's contractual relationship with the CFA features several missions: 
- to establish structural ties with student's host company by visiting the student on placement at least four times a year;

- to co-define, in collaboration with the in-company mentor, the mission(s) assigned to student in line with (i) the student's course program and competency development and (ii) the needs expressed by the host placement company;

- to ensure the learner grasps teachings given over the course of their program and help connect these teachings to the needs expressed by the placement company mentor.

The lessons learned from the past five years of CFA UNIV experience clearly demonstrate a strong positive relationship between strength of coordination in the orchestrated efforts of the company mentor/placement tutor tandem and the key metrics of sandwich-placement contract success (academic success, placement-student integration in the host company, and sandwich placement leavers staying on with the company...).

\section{Building Regional Brand As a Real Opportunity}

In a small island economy composed of $95 \%$ entrepreneurial microenterprises counting less than 10 employees, the sandwich-course training system provides a structural frame for companies hosting sandwich-placement students as a platform to unlock as-yet-untapped areal development potential.

\section{A Solution to the Issue of Ageing Labor Force}

In today's fast-changing professional environment, businesses have to constantly pipeline fresh new competencies to respond and adapt to structural change and the adaptation process hinges on constantly requalifying and refreshing their competency capital (Greenan, 1996). Increasingly ubiquitous and fast-evolving workplace technologies have created a shortage of qualified labor, due to the skills mismatch. With the ageing baby boomer cohort, these shortages will likely, if not already, come thick and fast, with a domino effect leading to a contracting workforce economy-wide. In today's booming knowledge economy, professional training for employees - regardless of their age bracket-is absolutely vital. Sandwich-course training brings solutions to these issues, as it enables cross-generational knowledge transfer between an experienced mentor and young student. It enables opt-in companies to continually refresh their competency sets and to continually revise their position, as the placement student hosted brings fresh eyes, fresh outlook, and a fresh grip on current technologies.

Furthermore, the age pyramid points to a spate of retirements in a few years' time (on top of the many baby-boomers already headed towards retirement), which is why so many of the island's companies have made workforce renewal a priority. A standout example is the local-branch banks, which mobilized the University of Corsica and CFA UNIV apprenticeships academy to resource a degree-level sandwich-course pipeline to train up the next generation of account managers. This initiative led to the professional-vocational degree in banking, which delivers fast-track vocationally-oriented training with lectures and input from a host of banking-industry professionals. The CFA UNIV needs to engineer its sandwich scheme offer to be ready to respond at time point $t$ to current operational and coming structural deficits in the Corsican economy. These ad hoc training modules must therefore be devised and designed as answers to one-time situations, with no thought to whether they could continue indefinitely. Based on this brief, there is a strong rationale for promoting other similarly operational responses, both to capture entrepreneurial needs and to adjust instructional capacity accordingly. In 
the field of accounting, a diploma combining a consensus-built qualification level and a strong sandwich-placement component is about to be rostered in the professional-vocational degree applied accounting.

\section{Multidimensionality of Sandwich Training: Adding Value Three Ways—For Student, Business, and the Community}

The thinking behind the sandwich-course training system enables deeper analysis and insight into the training-employment linkage, and indeed, it is through this process that the linkage is most clearly materialized. Scholarship may well have launched into intellectualized school-of-thought approaches to the entrepreneurial world, but the only concrete bridge between the two remains the sandwich course format with a tripartite agreement binding university and enterprise via the sandwich placement student. Seen through this prism, sandwich training drives both educational and economic growth. It can be defined as a multidimensional concept in which all the actors involved benefit from greater added value.

There are many reasons why companies are right to use the sandwich placement system-chiefly as a solution to train up qualified staff with the skills they specifically need or as a measure to address labor shortage or retention concerns.

Indeed, as stakeholder-partners, businesses actively participate in shaping the training system, on the academic side by collaborating on drafting French Ministerial Department of Education competency benchmarks, and on the business side by equipping their future employees with specific, technical, and technological knowledge. In effect, over and above foundational theory and practice, a sandwich student is essentially looking to receive more specific teaching, the "things you don't learn at school", chiefly the 101 of professional competency-real-world work experience.

Underpinning sandwich-course instruction is the production of multiple knowledge-sets requiring tight two-way school-enterprise cooperation. Here, the university-enterprise relationship takes on an absolutely pivotal role - for the student, who is looking to build a career; for the university, which lays the credibility and utility of its current (and future) course programs on the line for the island's key social and economic communities; and for the company, which is looking to fit training options to market constraints. Jean André Miniconi, President of the CGPME (Corsica-region union of small and medium organizations) which works in tight collaboration with the CFA UNIV, underscores the fact that "sandwich training is an opportunity for both lead entrepreneurs and the business itself. It enables them to integrate fresh new competencies and acquire additional skillsets - that's a huge asset for any business. The liaison between the CGPME and the CFA UNIV helps understand the course options on offer and strengthen the core university/enterprise relationship".

Furthermore, the consensus idea is that sandwich placements are expected to lead into long-term employment, but not all businesses can systematically offer open-ended employment contracts to follow through on a sandwich-placement agreement. Only 19\% of businesses currently propose open-ended employment contracts, with the remainder adopting a local community-first stance by training up students for other businesses (partners, subcontractors, and etc.). One such example is Télé Paese, as Franco Farsetti, CEO, explains, "through the work of the CFA UNIV and the University of Corsica, I see an exceptional standard of bright young sandwich-placement students. We are one of many microenterprises and we are delighted to see such a high standard of young talent applying to join us. Unfortunately, we are simply not big enough to keep hold of all our apprentices, but small as we are, it makes us proud to see them go on to join businesses like FR3 Corse (a public-service regional TV channel)". Electricity and Gas de France (EDF-GDF) Corse tells the same 
story, narrated here by Patrice Rossi, Chief HR Officer, "at the end of the day, apprenticeships have always been recruitment-oriented, but they also carry a social responsibility component turned towards training or even school-to-work transition for human-capital resources. We do not just scale our apprenticeship intake to fit our recruitment needs - if we did, we would be closing doors".

Ministry-sponsored career placement surveys led by the CFA UNIV converge with the message from business leaders. In fact, $84 \%$ of sandwich placement leavers that do not get fast-tracked into their host company enter the market (three months after graduating) - a figure that confirms the hypothesis that sandwich course training multiplies employability. However, all businesses, regardless of how they "use" sandwich placement training, consider it a talent pool.

Table 1 below gives a schematic picture of how the sandwich placement breaks down into added-value benefit—-for student, business, and wider community.

Table 1

Sandwich Placement Breaks Down

\begin{tabular}{|c|c|c|}
\hline For the business & For the placement student & For the placement student \\
\hline Qualify job-ready professionals & \multirow{2}{*}{$\begin{array}{l}\text { Obtain recognized and marketable job } \\
\text { qualifications }\end{array}$} & \multirow{2}{*}{$\begin{array}{l}\text { Ready the next generation for jobs in } \\
\text { promising fields }\end{array}$} \\
\hline Build up a productive resource & & \\
\hline \multirow{3}{*}{$\begin{array}{l}\text { Diversify and secure the recruitment } \\
\text { pipeline }\end{array}$} & \multirow{3}{*}{$\begin{array}{l}\text { In some cases, reconnect with the } \\
\text { education system }\end{array}$} & Progressive school-to-work transition \\
\hline & & Areal development \\
\hline & & Anticipate demographic patterns of \\
\hline \multirow{2}{*}{$\begin{array}{l}\text { Streamline, optimize the time needed for } \\
\text { onboarding }\end{array}$} & \multirow{2}{*}{$\begin{array}{l}\text { Realize how knowledge informs action } \\
\text { and vice versa }\end{array}$} & change \\
\hline & & $\begin{array}{l}\text { Stronger University-enterprise } \\
\text { engagement }\end{array}$ \\
\hline Take the workplace community forward & $\begin{array}{l}\text { Progressively take on career-developing } \\
\text { responsibilities }\end{array}$ & \multirow{4}{*}{$\begin{array}{l}\text { Continually refresh knowledge and } \\
\text { knowhow }\end{array}$} \\
\hline Promote continual re-benchmarking & $\begin{array}{l}\text { Learn teamwork skills to navigate the } \\
\text { professional environment }\end{array}$ & \\
\hline $\begin{array}{l}\begin{array}{l}\text { Develop lifelong learning adaptability in } \\
\text { collaborators }\end{array} \\
\end{array}$ & \multirow{2}{*}{$\begin{array}{l}\text { Develop lasting self-management and } \\
\text { adaptation abilities }\end{array}$} & \\
\hline $\begin{array}{l}\text { Strengthen organizational attachment and } \\
\text { retention }\end{array}$ & & \\
\hline
\end{tabular}

\section{Emergence of an Entrepreneurial Mindset}

Entrepreneurship can be defined as individuals, groups, or communities willing to take risks to engage capital (invest or pay a price) in some kind of "(ad)venture" that brings something new (innovation) and creative, by mobilizing and combining the optimal set of resources available (Julien \& Marchesnay, 1996).

The understanding of entrepreneurship owes much to the contributions of economist Joseph Schumpeter and the Austrian school of economic thought. For Schumpeter (1947), an entrepreneur is a person willing and able to convert an idea or invention into a successful innovation.

For Knight (1967) and Drucker (1970), entrepreneurship is about taking risk. Another definition of entrepreneurship describes a process of discovering, weighing up, and taking advantage of opportunities. This school of thought would define an entrepreneur as someone whose action is not guided by the resources they currently control, but by an insatiable drive to pursue an opportunity (Timmons, 1989). Pinchot (1985) is credited with coining the term "intrapreneuring" (and the concept of intrapreneurship) to describe entrepreneurial behaviors within a large organization. 
Fayolle and Verstraete (2005) defined entrepreneurship as a challenge assertively taken up by an individual (or a team of people united in the opportunity) creating and seizing a business opportunity (at least perceived or evaluated as such) where the payoff is not necessarily counted in terms of money, by leading an organizational venture that may spin off one or more entities, and created new value (with extra added value for an innovation) for stakeholders in the project's outcomes.

Paturel (2007) proposed a syncretic definition of entrepreneurship as starting out from an idea, exploiting an opportunity, via an organization that is first led, built from scratch or borrowed, and only consolidated later on, by a person or a team going through a big life frame shift, through a process that culminates in creating new value or economizing wastage of existing value. Seen through this prism, entrepreneurship is deeply embedded in the project-based approach.

Despite the array of definitions above, a key strand emerges, wherein the defining features of an entrepreneur are tenacious drive and initiative-oriented mindset-competencies that, ultimately, cannot be taught in school. Furthermore, entrepreneurship plays a decisive role for society, as it creates wealth and jobs. However, starting up a business is not an easy process and the entrepreneur needs help, guidance, and coaching. This is where the kind of learning offered by a sandwich course really pays off for the future entrepreneur.

It is said that not every sandwich-course student is geared up and ready for entrepreneurial leadership themselves, but they may be ready to "handle" someone else's initiative. Here, the courses and sectors geared to placement offers are liable to provide the market with a pipeline of talent that already has many of the skills and aptitudes needed to take on business initiatives.

It may be true that the job market is already flooded with managers, but the specifics of new or micro-enterprise ventures with opportunities for growth (and therefore job creation) call for individuals who can readily embrace both their policy direction and the multiple facets (not just functional facet) of their strategy, whether in terms of formulation or implementation. Even if a student lacks defiantly entrepreneurial talent or temperament, their understanding and awareness of the implications of new initiative will still be apt to serve the business start-up process. Ultimately, the impacts of sandwich-placement schooling policy on the entrepreneurial fiber can be collapsed into two big subsets that intertwine:

(1) Key understanding of entrepreneurship and intrapreneurship: Sandwich students on placement collaborate with C-level executives over their apprenticeship period are therefore trained to support the business leader on formulating and implementing initiatives and handling the many (and cross-disciplinary) subsequent implications across the company. When these people posses the second subset of competencies, they potentially become entrepreneurs;

(2) Initiative management: Apprenticeship learning stimulates entrepreneurial capacities connected to envisioneering (foresight), crafting a strategic vision, and creativity, but also crystallizing and implementing the strategy in routine daily management (strategic management). Training a HR to be self-sufficient and giving that resource empirical knowledge of the world of work will develop the cognitive abilities needed to take initiatives and create business.

In 2011, of the 72 sandwich placement leavers who found employment, six (8.3\%) had started up their own business - a figure that proves how the knowledge economy helps meet island-region needs.

\section{From Homo Economicus to Homo Alternans: A Reality Under Construction}

Homo economicus (a mock Latin locution borrowing on usages in paleoanthropology) is a theoretical 
model at the root of neoclassic economic theory on human behaviour. Homo economicus is rational, which is understood to mean a self-interested actor with preferences and the ability to make judgments toward his self-defined ends. If he prefers sport over cinema and cinema over TV, he will prefer sport over TV, which is the principle property of transitivity. He has the ability to maximize his wellbeing by optimally using his resources, thus maximizing utility (and not profit). He knows how to analyze and optimally anticipate the situation and events surrounding him so as to take decisions enabling utility maximization.

In microeconomics, these three terms are axiomatized as transitivity, completeness, and non-satiation. Economists often assimilate utility with wellbeing. The sum of the utilities of the individuals making up a society is considered social wellbeing. If these rational features are assigned to all economic agents and if the market is perfectly competitive, economic models that maximize each agent's utility can be built, i.e. that meet the sub-hypothesis of market efficiency.

In a context that has rocked the waged employment model (outsourcing, job insecurity, and looser/more flexible work conditions) and brought deep change in the employment landscape (individually-tailored jobs and job contracts), there are legitimate grounds to challenge the value and relevancy of HR metrics. HR metrics are typically operational indicators and evaluations of employee programs (training, pay, and etc.), and although sharp, their scope is only partial given the new job segmentations, variety of work conditions, and new contextual challenges that businesses have to contend with.

This is why, factoring in the definition of homo economicus and the lack of a HR component addressing the sandwich student's lifelong career in a fiercely competitive job market (France counts six million unemployed), this paper posits the following hypothesis - the individual who opts to build their career path project via a higher-education sandwich-course is going to maximize their knowledge of the company while potentializing their lifelong training capacity, and consequently boost their career-long employability. This paper has baptized this social-economic agent homo-alternans-a term etymologically rooted in the meaning of the word "alternance" (French for "sandwich course") dating to 1519 and the Latin alternans, from alternare, an adjective meaning "to alternate" and antonym of "continuous".

The career model championed by sandwich-placement training thus emerges as a professional model (Kanter, 1989), according to Culie (2007), specifying that career should be measured against the yardstick of skills/competencies developed. Patrice Rossi, Chief HR Officer-EDF-GDF Corsica, claimed that group policy is to foster an internal locus of career development. This paper finds that when someone joins a sandwich placement, they will have developed both the personal and organizational skillsets needed. This is why the sandwich placement leavers recruited make better and faster career progress. This paper cannot comprehensively define sandwich placement-leaver career trajectories as the career trajectory mapping would take too long and the CFA UNIV is still in its early days. However, prompted by the early feedback from the CFA UNIV, this paper can assert that employability is potentialized in sandwich-placement students. But what exactly is employability?

Employability is a construct conceptualized in an array of dimensions: a state, a professional position, i.e. an observable, or a like hood (chances), the career options, i.e. potential futures, beliefs, and value judgments. Here, homo alternans, who is more comprehensively preparing to enter the job market, is going to gain employability, which is defined in terms of capacity to fit the likelihoods and chances stemming from employability as defined above, and throughout their entire career. This is a social and economic actor readied to take the best decisions, due to a better-grounded representation of the world of work and, consequently, to more astutely read ahead in a perpetually shifting labor marketplace. 


\section{Conclusions}

This paper brings an analysis of the conservative yet value-adding benefits of sandwich placement-based higher education courses, seen through the prism of the CFA UNIV experience and its impact on how the socio-economic fabric of Corsica is structured. Conservative properties illustrated in the in-company mentor role enable the transfer of both technical competencies and the soft skills vital to navigating the world of work. The creation of added-value is visible on both the intrapreneurial front, where recruits in jobs classified French level I, II, and III training (entry at undergraduate, graduate, and masters-plus level) are key dynamic drivers in microenterprises and small businesses, and on the entrepreneurial front with the emergence of an entrepreneurship mindset as a non-negligible percentage of sandwich placement leavers going on to create or reactivate a business. Aptitudes such as versatility, self-management, and adaptation abilities are potentialized in students that have followed a sandwich course in higher education.

Ultimately, beyond the competency transfer and intellectual stimulation delivered specifically through this training framework, its focal aim is to effectively address local economy challenges - by raising the prospects of job creation and development (business entrepreneurship and internal talent development) - and, critically, HR challenges - by reinforcing organizations with people who are not homo economicus but a fresh new actor of the wider community: homo alternans.

\section{References}

Allen, T. D., \& Poteet, M. L. (1999). Developing effective mentoring relationships: Strategies from the mentor's viewpoint. The Career Development Quarterly, 48, 59-73.

Astier, P., Conjard, P., Devin, B., \& Olry, P. (2006). Acquire and pass on skills. Paris: ANACT Collection Studies and Documents.

Bandura, A. (1977). Social learning theory. Englewood Cliffs: Prentice Hall.

Bernardin, E., \& Krohmer, C. (2007). Importance of manager's implication within the framework of a training e-learning followed since the workstation. Proceedings from 18th Congress of AGRH, Fribourg, Suisse.

Boru, J. J., \& Leborgne, C. (1992). Towards the company guardian (Vers l'entreprise tutrice). Paris: Editions Entente.

Clénet, J., \& Demol, J. N. (2002). Researches and practices of sandwich-course in France: Approaches and their orientations. In C. Landry (Ed.), The sandwich training, the state of the practices and the researches. Québec: Presses de l'Université du Québec.

Culie. J. D. (2007). Put in perspective of the models of careers in the context of the poles of competitiveness: A critical review of literature. Proceedings from 18th Congress of AGRH : Tools, methods and models in GRH (Outils, modes et modèles en GRH), Fribourg.

Drucker, P. (1970). Entrepreneurship in business enterprise. Journal of Business Policy, 1, 12-21.

Duncan, G. J., \& Brooks-Gunn, J. (1997). Consequences of growing up poor. New York: Russell Sage Foundation.

Eby, L. T., \& Lockwood, A. (2005). Protégés' and mentors' reactions to participating in formal mentoring programs: A qualitative investigation. Journal of vocational behavior, 67(3), 441-458.

Eisenberger, R., Fasolo, P., \& Davis-LaMastro, V. (1990). Perceived organizational support and employee diligence, commitment, and innovation. Journal of applied psychology, 75(1), 51-59.

Fayolle, A., \& Verstraete, T. (2005). Paradigms and entrepreneurship. Review of the entrepreneurship, 4(1), 33-52.

Fredy-Planchot, A. (2007). Recognize the mentorship in a company. French review of management, 33(175), $23-32$.

Gerard, F. (2003). The evaluation of the efficiency of the training. Gestion, 3, 13-33.

Greenan, N. (1996). Technical progress and organizational changes: Their impact on the employment and the qualifications. Economy and statistics, 8(298), 35-44.

Hahn, C. Alexandre-Bailly, F., Geay, A., \& Vignon, C. (2008). Train the managers, when the sandwich course calls for discussion (Former les managers, quand l'alternance s'invite dans le débat).Vuibert, Paris.

Harris, R., Simons, M., Willis P., \& Carden P. (2003). Exploring complementarity in on and off job training for apprenticeships. International Journal of Training and development, 7(2), 82-92. 
Helfer, M. E., Keme, R. S., \& Drugman, R. D. (1997). The battered child (5th ed.). Chicago: University of Chicago Press.

Henry, W. A. (1990). Making the grade in today's schools. Time, 135, 28-31.

Hunt, D., \& Michael, C. (1983). Mentorship, a career training and development tool. Academy of management review, 8 , 475-485.

Jedliczka, D., \& Delahaye, J. (1994). Skills and sandwich course (Compétences et alternance). Paris: Éditions Liaisons.

Julien, P. A., \& Marchesnay, M. (1996). The entrepreneurship. Paris: Economica, édition Gestion poche.

Kanter, R. M. (1989). Careers and the wealth of nations: A macro-perspective on the structure and implications of careers. In M. Arthur, D. T. Hall, \& B. S. Lawrence (Eds.), Handbook of career theory (pp. 506-522). Cambridge: Cambridge University Press.

Knight, K. E. (1967). A descriptive model of the intra-firm innovation process. The Journal of Business, 40(4), 478-496.

Lacaze, D. (2004). The socialization of the new put on payroll in the company, an interactive learning (La socialisation des nouveaux salaries dans l'entreprise, un apprentissage interactif). In S. Guerrerro, J. L. Cerdin, \& A. Roger (Eds.), The career management, stakes and perspectives (pp. 65-84). Paris: Vuibert.

Lankau, M. J., \& Scandura, T. A. (2002). An investigation of personal learning in mentoring relationships: Content, antecedents, and consequences. Academy of Management Journal, 45(4), 779-790.

Luttringer, J. M. (1995). The sandwich course, the legal approach (L'alternance, approche juridique). In R. Poupard, Y. Lichtenberger, J. M. Luttringer, \& C. Merlin, (Eds.), Construire la formation professionnelle en alternance. Paris: Ed. d'Organisations.

Manville, C. (2006). Flexibility in employment and organizational implication, the stakes in right practices of GRH. Proceedings from Acts of the 17th congress of AGRH, Reims.

Mintzberg, H. (1982), Structure and dynamics of organizations. Paris: Éditions d'organisation.

Morin, L. \& Renaud S. (2009). The retention of the employees and the practices of training and remuneration: Inventory of fixtures of the North American literature in GRH, psychology and labour economics (La rétention des employés et les pratiques de formation et de rémunération: état des lieux de la littérature nord américaine en GRH, psychologie et économie du travail ). Proceedings from Actes du $20^{\text {ème }}$ congrès de l'AGRH, Toulouse.

Noe, R. (2000). Employee training and development. New-York: Irwin-McGraw-Hill.

O’Neil, J. M., \& Egan, J. (1992). Men's and women's gender role journeys: Metaphor for healing, transition, and transformation. In B. R. Wainrib (Ed.), Gender issues across the life cycle (pp. 107-123). New York, NY: Springer.

Orly, P., Conjard, P., \& Devin, B. (2006) .Acquire and pass on skills (Acquérir et transmettre des compétences). Éditions réseau ANACT.

Paille, P. (2009). The role of the superior and the colleagues in the retention of the human resources, the contributions of the multi-approach target (Le rôle du supérieur et des collègues dans la rétention des ressources humaines, apports de l'approche multi cibles). Revue de GRH.

Paille, P. (2004). Empirical examination on the multidimensional character of the normative commitment and on the links with the emotional and continuous commitments. Psychologie du travail et des organisations, 10, 327-339.

Paille, P. (2006). Commitment organizational and behavior of organizational citizenship. Revue de GRH, 60, 37-45

Paturel, R. (2007). Greatnesses and constraints of the entrepreneurship. International review of psychosociology, 13(31), 27-43.

Peretti, J. M. (2001). Every HR managers (Tous DR). Paris: Eyrolles, Éditions d'Organisations.

Pinchot, G. (1985). Intrapreneuring: Why don't have to leave the corporation to become an entrepreneur. New York: Harper \& Row.

Plath, S. (2000). The unabridged journals. New York: Anchor.

Rhoades, L., \& Eisenberger, R. (2002). Perceived organisational support: A review of the literature. Journal of applied psychology, 87(4), 698-714.

Schein, E. (1978). Career dynamics: Matching individual and organizational needs. Reading: Addison Wesley publishing Co..

Schultz, S. (2005, December 28). Calls made to strengthen state energy policies. The Country Today, pp. 1A, $2 \mathrm{~A}$.

Schumpeter, J. A. (1947). The creative response in economic history. Journal of Economic History, 7, 149-159.

Stinglhamber, F., \& Vandenberghe, C. (2003). Organizations and supervisors as sources of support and targets of commitment, a longitudinal study. Journal of organizational behaviour, 24(3), 251-270.

Storaï, C., Riniéri, L., \& Boulenger, M. (2014). Sandwich-course training in higher education as a major strategic thrust regional policy of professional training: Lessons learned from the pioneering example of the University Institute of Technology Corsica. Chinese Business Review, 13(2), 101-110. 
Thevenet, M. (1992). Involve the people in the company. Paris: Éditions Liaisons.

Thevenet, M., Dejoux, C., Marbot, E., \& Normand, E. (2007). Functions RH (Fonctions RH). Paris: Pearson Education.

Timmons, J. (1989). The entrepreneurial mind. New Boston: Brick House Publishing Company.

Vanderpotte, G. (1992). The tutorales functions in the sandwich courses (Report to the Minister of work, labour and vocationnal training, Ministry of labour, Paris).

Veillard, L. (2004). The mentorship in the test of the social and technical specificities of the company. Education permanent, 159, 117-138. 